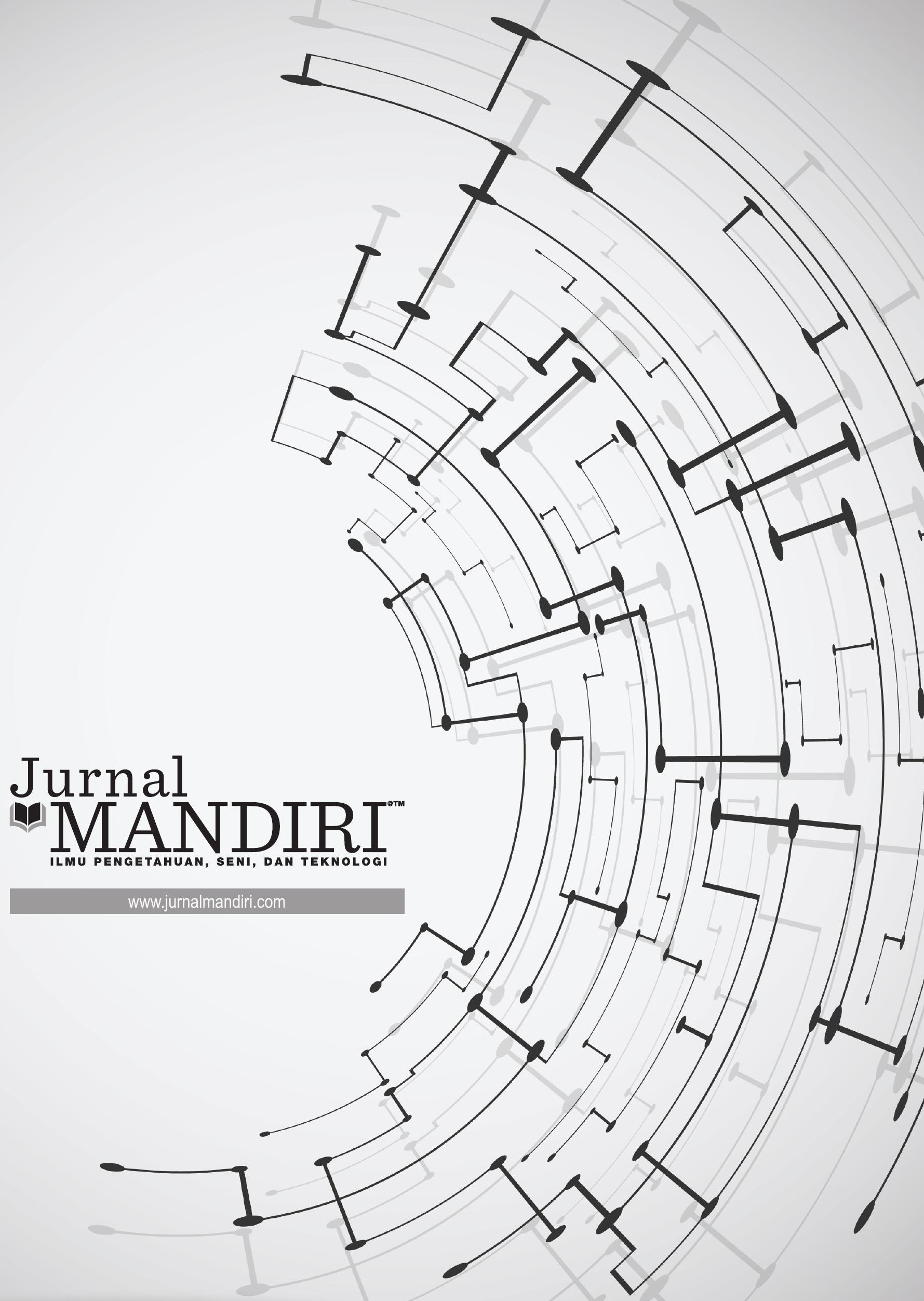


ISSN : 2580-3220, E-ISSN : 2580-4588

J. Mandiri., Vol. 3, No. 1, Juni 2019 (20 - 36)

(C)2018 Lembaga Kajian Demokrasi

dan Pemberdayaan Masyarakat (LKD-PM)

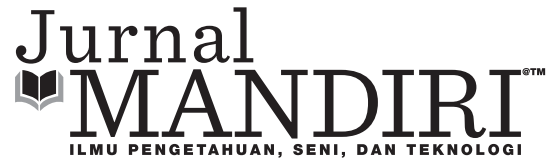

\title{
ANALISIS RASIO ROA DAN ROE DALAM MENILAI TINGKAT KESEHATAN PADA PT BANK MANDIRI (PERSERO) TBK TAHUN 2012 - 2017
}

\author{
Sutiman \\ Fakultas Ekonomi, Universitas Pamulang \\ soetiman2014@gmail.com
}

\begin{abstract}
Abstrak
Tujuan dalam penulisan ini adalah Untuk mengetahui dan menganalisis tingkat kesehatan rasio Return on Asset (ROA) pada PT Bank Mandiri (Persero) Tbk tahun 2012-2017, untuk mengetahui dan menganalisis tingkat kesehatan rasio Return on Equity (ROE) pada PT Bank Mandiri (Persero) Tbk tahun 2012-2017, ntuk mengetahui dan menganalisis kinerja keuangan PT Bank Mandiri (Persero) Tbk berdasarkan rasio Return on Asset (ROA) dan rasio Return on Equity (ROE) tahun 2012-2017. Populasi yang digunakan dalam penelitian ini adalah laporan keuangan PT Bank Mandiri (Persero) Tbk dan sampenya berupa neraca, dan laporan laba rugi PT Bank Mandiri (Persero) Tbk dan anak perusahaan pada tahun 2012 sampai tahun 2017 yang diperoleh dari website resmi PT Bank Mandiri (Persero) Tbk yaitu http://www.Mandiri.co.id dan Otoritas Jasa Keuangan yaitu https://ojk.go.id. Metode pengumpulan data yang digunakan dalam penelitian ini adalah data sekunder, dengan teknik yang digunakan Kepustakaan (Library Research), Dokumentasi, Internet Research penelitian ini menggunakan metode analisis deskriptif dan kuantitatifPada perhitungan Return on Asset (ROA) pada PT Bank Mandiri (Persero) Tbk, menunjukkan bahwa kondisi perusahaan "sehat" dengan memperoleh nilai rata-rata Return on Asset (ROA) sekitar 2,78\% atau lebih besar dari (> 2,50\%) Statistik Perbankan Indonesia.Pada perhitungan Return on Equity (ROE) pada PT Bank Mandiri (Persero) Tbk, menunjukkan bahwa kondisi perusahaan "sehat" dengan memperoleh nilai rata-rata Return on Equity (ROE) sekitar 16,99\% atau lebih besar dari (> 14,61\%) Statistik Perbankan Indonesia. Kinerja keuangan pada PT. Bank Mandiri (Persero) Tbk yang dilihat dari hasil rasio Return on Asset (ROA) dan Return on Equity (ROE) menunjukkan bahwa kondisi perusahaan "sehat".
\end{abstract}

Kata Kunci : Rasio, ROA, REO dan Kesehatan

\section{Abstract}

The purpose of this paper is to find out and analyze the level of health of the Return on Assets (ROA) ratio of PT Bank Mandiri (Persero) Tbk in 2012-2017, to find out and analyze the level of health Return on Equity (ROE) ratio at PT Bank Mandiri (Persero ) Tbk in 2012-2017, to know and analyze the financial performance of PT Bank Mandiri (Persero) Tbk based on the Return on Assets (ROA) ratio and the Return on Equity (ROE) ratio for 2012-2017. The population used in this study is the financial statements of PT Bank Mandiri (Persero) Tbk and its accounts in the form of balance sheets, and income statements of PT Bank Mandiri (Persero) Tbk and subsidiaries from 2012 to 2017 obtained from the official website of PT Bank Mandiri (Persero) Tbk 
namely http://www.Mandiri.co.id and the Financial Services Authority, namely https://ojk.go.id.The data collection method used in this study is secondary data, with techniques used in the Library (Library Research), Documentation, Internet Research. This research uses descriptive and quantitative analysis methods. In the calculation of Return on Assets (ROA) at PT Bank Mandiri (Persero) Tbk, indicates that the condition of a "healthy" company by obtaining an average value of Return on Assets (ROA) of around 2.78\% or greater than (>2.50\%) Indonesian Banking Statistics. In the calculation of Return on Equity (ROE) at PT Bank Mandiri (Persero) Tbk, it shows that the condition of the company is "healthy" by obtaining an average value of Return on Equity (ROE) of around 16.99\% or greater than (> $14.61 \%$ ) Indonesian Banking Statistics. Financial performance at PT. Bank Mandiri (Persero) Tbk which is seen from the results of the Return on Assets (ROA) and Return on Equity (ROE) ratio shows that the condition of the company is "healthy".

Keywords : Ratio, ROA, REO and Health

\section{PENDAHULUAN}

\section{Latar Belakang}

Perbankan mempunyai peran yang besar dalam kegiatan perekonomian hal ini dikarenakan perbankan memiliki fungsi utama sebagai suatu media yang dapat menghimpun dan menyalurkan dana ke masyarakat. Bank dengan fungsi tersebut berperan dalam kegiatan pembangunan nasional, yaitu untuk meningkatkan pertumbuhan dan pemerataan pembangunan ke arah peningkatan taraf hidup masyarakat dengan memberikan pelayanan yang baik dan bermanfaat bagi perekonomian.

Dalam menciptakan kepercayaan masyarakat perbankan harus meningkatkan kualitas pelayanaan kepada nasabahnya. Sehingga perbankan dapat menerapkan tata kelola dan kesehatan perbankan dengan baik. Saat nasabah tidak merasa puas, tanpa disadari telah mengancam reputasi bank. Inilah yang pernah terjadi di tengah kita : krisis perbankan nasional 1998.

Seiring dengan pulihnya kepercayaan nasabah terhadap industri perbankan Indonesia setelah mengalami krisis, kinerja keuangan perbankan mulai mengalami peningkatan. Perkembangan perbankan yang semakin meningkat berimplikasi terhadap persaingan di industri perbankan yang semakin kompetitif dalam menarik nasabah dalam menyusun program loyalitas agar memperoleh tingkat profit yang lebih sehat, terutama bagi nasabah korporasi dan komersial, serta membangun kepercayaan nasabah.

Salah satu syarat yang dapat mempengaruhi kepercayaan dari masyarakat adalah tingkat kesehatan suatu bank. Sehingga, sangat diperlukan usaha untuk menciptakan dan memelihara kesehatan bank tersebut. Peran penting bank dalam menunjang perekonomian negara merupakan salah satu alasan mengapa kinerja keuangan perbankan senantiasa di analisis untuk mengetahui tingkat kesehatannya. Bank dikatakan sehat apabila dapat menjaga dan memelihara kepercayaan masyarakat, dalam menjalankan fungsi intermediasi, membantu kelancaran lintas bayar dan dapat digunakan pemerintah dalam melaksanakan berbagai kebijakan, khususnya kebijakan moneter.

Pelaksanaan penilaian terhadap kesehatan perbankan telah diatur berdasarkan pada lima komponen yaitu Capital, Assets, Management, Earning, dan Liquidity dikenal dengan metode CAMEL. Sesuai dengan ketetapan pemerintah melalui Bank Indonesia mengeluarkan Surat Edaran Bank Indonesia No. 9/24/DPbS tanggal 30 Oktober 2007 dan Peraturan Bank Indonesia No. 9/1/PBI/2007 dimana penilaian tingkat kesehatan (kinerja) dan surat keputusan direksi Bank Indonesia No. 30/12/kep/DIR/2007.

PT Bank Mandiri (Persero) Tbk merupakan salah satu Bank Umum Milik Negara terbesar di indonesia jika dilihat dari sektor jumlah aset, pinjaman, dan deposito. PT Bank Mandiri (Persero) Tbk juga telah berhasil mencetak perkembangan yang signifikan dalam pelayanan di sektor usaha kecil dan menengah (UKM) dan nasabah ritel. Dan beberapa tahun terakhir tepatnya pada 
tahun 2017 PT Bank Mandiri (Persero) Tbk menjadi salah satu penerima penghargaan dari Bank Indonesia 2017 dengan nama kategori Bank Pendukung Pengendalian Moneter Rupiah dan Valas terbaik dari 16 (enam belas) kategori dan 30 (tiga puluh) penghargaan yang diberikan kepada individu, korporasi, dan perbankan, serta media (https//:www.bi.go.id/, diakses pada tanggal 08 april 2018 pukul 03:54).

Selain itu, Direktur Riset Info bank, Eko B Supriyanto mengungkapkan di Hotel Atlet Century Park, Jakarta. Bahwa berdasarkan peringkat kepemilikan modal di atas Rp50 triliun, PT Bank Mandiri (Persero) Tbk memperoleh rating tertinggi dengan predikat sangat bagus. Dengan menggunakan lima metode penilaian yaitu Permodalan Capital Adequacy Ratio (CAR), Aktiva Produktif Non Performing Loan (NPL) dan Pemenuhan Penyisihan Peng_hapusan Aktiva (PPPA), Profitabilitas Return on Assest (ROA) dan Return on Equity (ROE), Likuiditas Loan to Deposit Ratio (LDR) dan Loan to Asset Ratio (LAR), Efisiensi (Beban Operasional Pendapatan Operasional (BOPO) dan Net Interest Margin (NIM).

Pada penelitian ini penulis akan menggunakan metode penilaian Return on Assets (ROA), Return on Equity (ROE) saja.

Return on Assets (ROA) atau disebut juga rentabilitas ekonomi untuk mengukur laba sebelum pajak dengan total aktiva yang dimiliki. Return on Equity (ROE) atau disebut juga rentabilitas modal sendiri untuk mengukur seberapa banyak keuntungan yang menjadi hak pemilik modal sendiri.

Berikut adalah data pertumbuhan kinerja keuangan PT Bank Mandiri (Persero) Tbk dari tahun 2012 sampai dengan tahun 2017.

\begin{tabular}{|c|c|c|c|c|}
\hline \multicolumn{5}{|c|}{$\begin{array}{l}\text { Tabel 1.2. Data Pertumbuhan Rasio Keuangan } \\
\text { PT Bank Mandiri (Persero) Tbk Tahun 2012-2017 }\end{array}$} \\
\hline \multicolumn{5}{|c|}{ Dalam Persen (\%) } \\
\hline Tahun & ROA & Naik (t) Turun (-) & ROE & Naik (t) Turun (-) \\
\hline 2012 & 3,23 & - & 31,76 & - \\
\hline 2013 & 3,28 & 0,05 & 21,21 & 10,55 \\
\hline 2014 & 3,04 & $-0,24$ & 17,29 & $-3,92$ \\
\hline 2015 & 2,90 & $-0,14$ & 20,18 & 2,89 \\
\hline 2016 & 1,79 & $-1,11$ & 9,55 & $-10,63$ \\
\hline 2017 & 2,41 & 0,62 & 12,61 & 3,06 \\
\hline
\end{tabular}

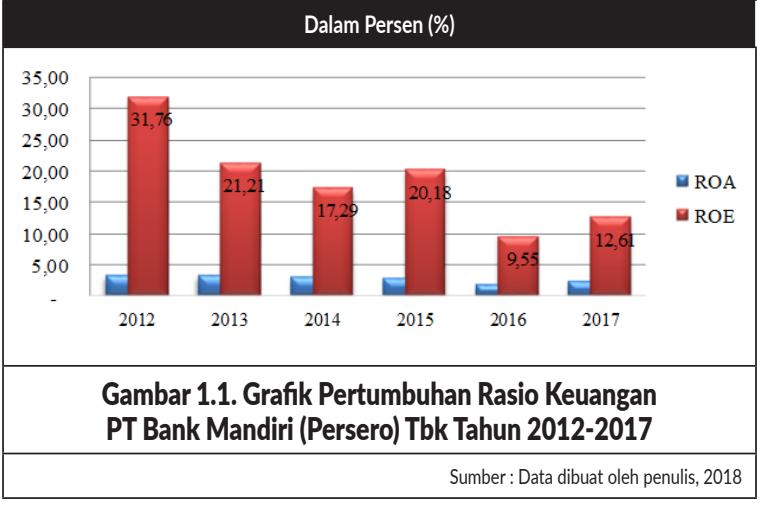

Berdasarkan tabel 1.2 dan gambar 1.1 diatas dapat dilihat bahwa pertumbuhan rasio keuangan PT Bank Mandiri (Persero) Tbk pada tahun 2012 sampai tahun 2017, terlihat pergerakan rasio Return on Asset PT Bank Mandiri (Persero) Tbk tidak stabil. Dari tahun 2012 sampai tahun 2013 mengalami kenaikan sebesar $0,05 \%$ menjadi sebesar 3,28\%, tetapi pada tahun 2014 sampai tahun 2016 mengalami penurunan secara berkala yaitu sebesar $0,24 \%, 0,14 \%, 1,11 \%$ menjadi sekitar 3,04\%, 2,90\%, 1,79\%. Dan kembali mengalami peningkatan sekitar 0,62\% menjadi sekitar 2,41\%.

Sementara itu, rasio Return on Equity (ROE) PT Bank Mandiri (Persero) Tbk cenderung fruktuatif dari tahun 2012 sampai tahun 2013 mengalami peningkatan yang cukup signifikan sekitar $10,55 \%$ menjadi sekitar $21,21 \%$, di tahun 2014 mengalami penurunan sekitar 3,92\% menjadi sekitar 17,29\% dan tahun 2015 kembali mengalami peningkatan sekitar 20,18\%. Tahun 2016 kembali turun secara signifikan sekitar 10,63\% menjadi sekitar 9,55\%, dan kembali mengalami peningkatan sekitar $3,06 \%$ menjadi sekitar $12,61 \%$.

Mengingat pentingnya peran perbankan dan semakin berkembangnya perbankan di Indonesia, maka diperlukan peraturan yang bertujuan untuk menjaga kepercayaan masyarakat terhadap aktivitas perbankan. Oleh sebab itu, Bank Indonesia menerbitkan peraturan baru mengenai tata pelaksanaan penilaian tingkat kesehatan bank, yaitu Peraturan Bank Indonesia Nomor: 13/1/PBI/2011 tentang penilaian tingkat kesehatan bank umum. Peraturan ini menggantikan penilaian CAMELS dalam $S \neg \neg$ E BI No. 6/23/DPNP tanggal 31 Mei 2004. 
Berdasarkan fenomena diatas, maka peneliti tertarik untuk melakukan penelitian tentang penilaian kesehatan berdasarkan kinerja keuangan perbankan dengan menggunakan rasio keuangan. Oleh karena itu peneliti memilih judul "Analisis Rasio ROA dan ROE Dalam Menilai Tingkat Kesehatan Pada PT Bank Mandiri (Persero) Tbk Tahun 2012 - 2017”.

\section{Identifikasi Masalah}

Berdasarkan latar belakang diatas, maka permasalahan yang dapat diidentifikasi adalah sebagai berikut :

1. Return on Asset (ROA) PT Bank Mandiri (Persero) Tbk cenderung tidak stabil.

2. Return on Equity (ROE) PT Bank Mandiri (Persero) Tbk cenderung mengalami fruktuatif.

3. Tingkat Kinerja keuangan PT Bank Mandiri (Persero) Tbk memperoleh rating tertinggi dengan predikat sangat bagus

\section{Pembatasan Masalah}

Untuk menghindari terjadinya pembahasan yang terlalu melebar serta terbatasnya waktu peneliti dalam melakukan penelitian, maka peneliti membatasi hanya pada hal-hal sebagai berikut:

1. Ruang Lingkup

a. Data penelitian ini peneliti mengambil data yang bersumber dari laporan keuangan PT Bank Mandiri (Persero) Tbk 31 Desember 2012 sampai dengan 31 Desember 2017 yang dapat di unduh dari situs resmi PT Bank Mandiri (Persero) Tbk di http://www.Mandiri.co.id dan Otoritas Jasa Keuangan yaitu https://ojk. go.id.

b. Penelitian dan pengambilan data ini dilaksanakan pada bulan April 2018.

2. Return on Asset (ROA) merupakan rasio untuk mengukur laba sebelum pajak dengan total aset atau rasio untuk memperoleh laba secara keseluruhan.

3. Return on Equity (ROE) merupakan rasio untuk mengukur laba setelah pajak dengan modal sendiri atau rasio untuk menunjukkan efesiensi penggunaan modal sendiri.

\section{Perumusan Masalah}

Berdasarkan identifikasi masalah dan pembatasan masalah diatas, maka penulis merumuskan masalah yang akan diteliti sebagai berikut:

1. Bagaimana tingkat kesehatan rasio Return on Asset (ROA) pada PT Bank Mandiri (Persero) Tbk tahun 2012-2017?

2. Bagaimana tingkat kesehatan rasio Return on Equity (ROE) pada PT Bank Mandiri (Persero) Tbk tahun 2012-2017?

3. Bagaimana kinerja keuangan PT Bank Mandiri (Persero) Tbk berdasarkan rasio Return on Asset (ROA) dan rasio Return on Equity (ROE) tahun 2012-2017?

\section{Analisis Kinerja Keuangan}

\section{Definisi Analisis Kinerja Keuangan}

Menurut Munawir (2010:30) kinerja keuangan merupakan satu diantara dasar penilaian mengenai kondisi keuangan perusahaan yang dilakukan berdasarkan analisa terhadap rasio keuangan perusahaan.

Kinerja keuangan adalah penentuan secara periodik tampilan keuangan berdasarkan sasaran, standar dan kinerja yang telah ditetapkan sebelumnya. Kinerja keuangan dapat dinilai dari kinerja untuk tahun yang lalu maupun yang sedang berjalan dengan menganalisis laporan keuangan sehingga, dapat menggambarkan dengan kondisi kesehatan keuangan perusahaan.

2. Tahap-tahap Dalam Menganalisis Kinerja

\section{Keuangan}

Penilaian kinerja setiap perusahaan berbeda-beda tergantung ruang lingkup bisnis yang dijalankan. Menurut Irham Fahmi (2014:240), ada 5 (lima) tahap dalam menganalisis kinerja keuangan suatu perusahaan secara umum, yaitu :

a. Melakukan review terhadap data laporan keuangan.

Review disini dilakukan dengan tujuan agar laporan keuangan yang sudah dibuat tersebut sesuai dengan penerapan kaidah-kaidah yang berlaku umum dalam dunia akuntansi, sehingga dengan demikian hasil laporan keuangan ter- 
sebut dapat dipertanggungjawabkan.

b. Melakukan perhitungan.

Penerapan metode perhitungan disesuaikan dengan kondisi dan permasalahan yang sedang dilakukan sehingga hasil dari perhitungan tersebut akan memberikan suatu kesimpulan sesuai dengan analisis yang diinginkan.

c. Melakukan perbandingan terhadap hasil perhitungan yang diperoleh.

Dari hasil perhitungan yang sudah diperoleh tersebut kemudian dilakukan perbandingan dengan hasil hitungan berbagai perusahaan lainnya. Metode yang paling umum digunakan untuk melakukan perbandingan dari perhitungan kinerja ke uangan ada tiga, yaitu :

1) Times series analysis, yaitu membandingkan antar waktu atau periode dengan tujuan itu nantinya akan terlihat pada grafik.

2) Cross sectional approach, yaitu melakukan perbandingan terhadap hasil perhitungan rasio-rasio yang telah dilakukan antar perusahaan dalam ruang lingkup yang sejenis yang dilakukan secara bersamaan.

3) Combine Analysis, yaitu mengkombinasikan cross section dan time series analysis.

Dari hasil penggunaan ketiga metode ini diharapkan nantinya akan diperoleh kesimpulan yang menyatakan posisi perusahaan tersebut berada dalam kondisi sehat atau tidak sehat.

d. Melakukan penafsiran (interpretation) terhadap berbagai permasalahan yang ditemukan.

Pada tahap ini seorang analis melihat kinerja keuangan perusahaan setelah dilakukan ketiga tahap tersebut maka selanjutnya dilakukan penafsiran untuk melihat apa-apa saja permasalahan dan kendala-kendala yang dialami oleh perusahaan.

e. Mencari dan memberikan pemecahan masalah (solution) terhadap berbagai permasalahan yang ditemukan.

Pada tahap terakhir ini setelah ditemukan berbagai permasalahan yang dihadapi maka seorang analis harus mencari solusi guna memberikan suatu masukan agar apa yang menjadi kendala dan hambatan selama ini dapat diselesaikan.

\section{Penilaian Tingkat Kesehatan}

Menurut Totok dan Nuritomo (2014:73) dalam Bernadetha Dian Septiana (2015:7) bahwa kesehatan suatu bank dapat diartikan sebagai kemampuan suatu bank untuk melakukan kegiatan operasional perbankan secara normal dan mampu memenuhi semua kewajibannya dengan baik dengan cara-cara yang sesuai dengan peraturan perbankan yang berlaku.

Tingkat kesehatan bank merupakan hasil penilaian atas berbagai aspek yang berpengaruh terhadap kondisi atau kinerja suatu bank. Tingkat kesehatan bank juga merupakan hasil penilaian kualitatif atas berbagai aspek yang berpengaruh terhadap kondisi atau kinerja suatu bank melalui penilaian faktor permodalan, kualitas asset, manajemen, rentabilitas, dan likuiditas.

Penilaian ini bertujuan untuk menentukan apakah bank tersebut dalam kondisi sehat atau tidak sehat sehingga Bank Indonesia sebagai pengawas dan pembina bankbank dapat memberikan arahan atau petunjuk bagaimana bank tersebut harus dijalankan atau bahkan diberhentikan dalam kegiatan operasinya.

\section{Likuiditas (Liquidity)}

\section{Pengertian Likuiditas (Liquidity)}

Likuiditas merupakan rasio yang digunakan untuk mengukur kemampuan perusahaan dalam memenuhi kewajiban jangka pendeknya yang segera jatuh tempo. Likuiditas diperlukan kepentingan analisis kredit atau analisis risiko keuangan. Bagi bank rasio ini digunakan untuk mengukur kemampuan bank dalam membayar kembali pencairan dana para deposannya pada saat ditagih serta dapat mencukupi permintaan 
kredit yang telah diajukan. Semakin sebesar rasio ini, maka semakin likuid perusahaan yang bersangkutan (Kasmir, 2016:221).

\section{Jenis-Jenis Likuiditas (Liquidity)}

Rasio Likuiditas (liquidity) dapat diukur dengan menggunakan beberapa rasio sebagai berikut :

\section{a. Current Ratio (CR)}

Current Ratio (CR) atau rasio lancar merupakan rasio yang digunakan untuk mengukur kemampuan bank dalam membayar utang jangka pendek yang segera jatuh tempoh pada saat ditagih secara keseluruhan (Kasmir, 2016 :134).

Rumus untuk menghitung Current Ratio (CR) dapat dirumuskan sebagai berikut :

\begin{tabular}{|c|c|}
\hline \multicolumn{2}{|c|}{ Current Ratio $=\frac{\text { Current Asset }}{\text { Current Liabilities }} \times 100 \%$} \\
\hline \multicolumn{2}{|c|}{ Gambar 2.1. Rumus Menghitung Current Ratio (CR) } \\
\hline & Sumber: Kasmir, (2016:134) \\
\hline \multicolumn{2}{|c|}{$\begin{array}{l}\text { Tabel 2.1. Matriks Kategori Komponen } \\
\text { Likuiditas Current Ratio (CR) }\end{array}$} \\
\hline Kategori & Hasil Rasio \\
\hline Sehat & $C R>200 \%$ \\
\hline Tidak Sehat & $C R>200 \%$ \\
\hline
\end{tabular}

b. Quick Ratio (QR)

Quick Ratio (QR) atau rasio sangat lancar merupakan rasio yang digunakan untuk mengukur kemampuan bank dalam memenuhi kewajibannya terhadap para deposan (pemilik simpanan giro, tabungan, dan deposito) dengan harta yang paling likuid yang dimiliki oleh bank (Kasmir, 2016 : 221).

Rumus untuk menghitung Quick Ratio (QR) dapat dirumuskan sebagai berikut :

Quick Ratio $=\frac{\text { Cash Assets }}{\text { Total Deposit }} \times 100 \%$
Gambar 2.2. Rumus Menghitung Quick Ratio (QR)
Sumber: Kasmir, (2016:221)

\begin{tabular}{c|c|}
\hline \multicolumn{2}{c|}{$\begin{array}{c}\text { Tabel 2.2. Matriks Kategori Komponen } \\
\text { Likuiditas Quick Ratio (QR) }\end{array}$} \\
\hline Kategori & Hasil Rasio \\
\hline Sehat & QR $>15 \%-20 \%$ \\
\hline Tidak Sehat & QR $<15 \%-20 \%$ \\
\hline Sumber : SE BI No. 6/10/PBU 2004 tanggal 12 April 2004 dalam Nurul Hidayati \& Sri Utiyati, (2013:11). \\
\hline
\end{tabular}

c. Cash Ratio (CR)

Cash Ratio (CR) merupakan rasio yang digunakan untuk mengukur seberapa besar uang kas yang tersedia untuk membayar utang (Kasmir, 2016: 224).

Rumus untuk menghitung Cash Ratio (CR) dapat dirumuskan sebagai berikut :

\begin{tabular}{|c|c|c|}
\hline \multicolumn{3}{|c|}{ Cash Ratio $=\frac{\text { Liquid assets }}{\text { Short Term borrowing }} \times 100 \%$} \\
\hline \multicolumn{3}{|c|}{ Gambar 2.3. Rumus Menghitung Cash Ratio (CR) } \\
\hline & Sumber: $\mathrm{K}$ & (asmir, (2016:224) \\
\hline \multicolumn{3}{|c|}{ Tabel 2.3. Matriks Kategori Komponen Likuiditas Cash Ratio (CR) } \\
\hline Kategori & Hasil Rasio & \\
\hline Sehat & $C R>80 \%$ & \\
\hline Tidak Sehat & $C R<80 \%$ & \\
\hline
\end{tabular}

d. Banking Ratio (BR)

Banking Ratio (BR) merupakan rasio yang digunakan untuk mengukur tingkat likuiditas bank dengan cara membandingkan jumlah kredit yang disalurkan dengan jumlah deposito yang dimiliki oleh bank (Kasmir, 2016:223).

Rumus untuk menghitung Banking Ratio (BR) dapat dirumuskan sebagai berikut :

\begin{tabular}{|c|}
\hline Banking Ratio $=\frac{\text { Total Loans }}{\text { Total Deposit }} \times 100 \%$ \\
\hline Gambar 2.4 Rumus Menghitung Banking Ratio (BR) \\
\hline Sumber: Kasmir, (2016:223) \\
\hline
\end{tabular}

\begin{tabular}{|c|c|}
\hline \multicolumn{2}{|c|}{ Tabel 2.4. Matriks Kategori Banking Ratio (BR) } \\
\hline Kategori & Hasil Rasio \\
\hline Sehat & BR $>75 \%-85 \%$ \\
\hline Tidak Sehat & BR $<75 \%-85 \%$ \\
\hline Sumber : SE BI No. 6/10/PBU 2004 tanggal 12 April 2004 dalam Nurul Hidayati \& Sri Utiyati, (2013:11) \\
\hline
\end{tabular}


e. Loan to Deposito Ratio (LDR)

Loan to Deposit Ratio (LDR) merupakan perbandingan antara jumlah kredit yang diberikan oleh bank (tidak termasuk antar bank) dibandingkan dengan jumlah dana yang diterima (tidak termasuk antar bank) (Lalu Gede Sava Ahmad, 2013:5).

Rumus untuk menghitung Loan to Deposit Ratio (LDR) dapat dirumuskan sebagai berikut :

\begin{tabular}{|c|c|}
\hline Loan to Deposit Ratio $=\frac{\text { Kredit }}{\text { Dana Pihak Ketiga }} \times 100 \%$ \\
\hline Gambar 2.5. Rumus Menghitung Loan to Deposit Ratio (LDR) \\
\hline \multicolumn{2}{|c|}{ Sumber : Lalu Gede Sava Ahmad, (2013:5) } \\
\hline Tabel 2.5. Matriks Kategori Loan to Deposit Ratio (LDR) \\
\hline Kategori & Hasil Rasio \\
\hline Sehat & LDR $<94,09 \%$ \\
\hline Tidak Sehat & LDR $>94,09 \%$ \\
\hline & Sumber: SPI- Vol. 16 No. 10, September 2018 \\
\hline
\end{tabular}

\section{Solvabilitas (Leverage)}

\section{Definisi Solvabilitas}

Menurut Kasmir (2016:229) Rasio Solvabilitas bank merupakan ukuran kemampuan bank dalam mencari sumber dana untuk membiayai kegiatannya. Rasio ini digunakan untuk mengukur kekayaan bank untuk melihat efisiensi bagi pihak manajemen bank tersebut.

Dalam rasio solvabilitas terdapat jenisjenis sebagai berikut:

a. Primary Ratio (PR)

Primary Ratio (PR) merupakan rasio yang digunakan untuk mengukur apakah permodalan yang dimiliki sudah memadai atau sejauh mana penurunan yang terjadi dalam total aset dapat ditutupi oleh capital equity.

Rumus untuk menghitung Primary Ratio (PR) dapat dirumuskan sebagai berikut:

$$
\text { Primary Ratio }=\frac{\text { Equity Capital }}{\text { Total Assets }} \times 100 \%
$$

b. Risk Assets Ratio (RAR)

Risk Assets Ratio (RAR) merupakan rasio yang digunakan untuk mengukur kemungkinan penurunan risk assets ratio (risiko Asset).

Rumus untuk menghitung Risk Assets Ratio (RAR) dapat dirumuskan sebagai berikut:

\begin{tabular}{|c|}
\hline Risk Assets Ratio $=\frac{\text { Equity Capital }}{\text { Total Assets }- \text { Cash Assets }- \text { Securities }} \times 100 \%$ \\
\hline Gambar 2.7. Rumus Menghitung Risk Assets Ratio (RAR) \\
\hline Sumber : Kasmir, (2016:230) \\
\hline
\end{tabular}

c. Secondary Risk Ratio (SRR)

Rasio ini digunakan untuk mengukur penurunan aset yang mempunyai risiko lebih tinggi.

Rumus untuk menghitung Secondary Risk Ratio (SRR) dapat dirumuskan sebagai berikut:

\begin{tabular}{|c|}
\hline Secondary Risk Ratio $=\frac{\text { Equity Capital }+ \text { Reserve for Loan Losses }}{\text { Secondary } \text { Risk Assets }} \times 100 \%$ \\
\hline Gambar 2.7. Rumus Menghitung Secondary Risk Ratio (SRR) \\
\hline Sumber : Kasmir, (2016:232) \\
\hline
\end{tabular}

\section{Aktivitas (Activity) \\ Definisi Aktivitas}

Menurut Kasmir (2016:172) aktivitas merupakan rasio yang digunakan untuk mengukur efektivitas perusahaan dalam menggunakan aktiva yang dimilikinya dalam melaksanakan aktivitas sehari-hari. Dari hasil pengukuran dengan rasio aktivitas ini akan terlihat apakah perusahaan lebih efisien dan efektif dalam mengelola asset yang dimilikinya atau mungkin justru sebaliknya.

\section{Jenis-Jenis Aktivitas}

a. Perputaran Piutang Receivable Turn Over (RTO)

Perputaran Piutang Receivable Turn Over (RTO) merupakan rasio yang digunakan untuk mengukur berapa lama penagihan piutang selama satu periode atau berapa kali dana yang ditanam dalam piutang ini berputar dalam satu periode.

Rumus untuk menghitung Receivable Turn Over (RTO) dapat dirumuskan sebagai 
berikut :

\begin{tabular}{|c|}
\hline Receivable Turn Over $=\frac{\text { Penjualan } k r e d i t}{\text { Piutang }}$ \\
\hline Gambar 2.8. Rumus Menghitung Receivable Turn Over (RTO) \\
\hline Sumber: Kasmir, (2016:176) \\
\hline
\end{tabular}

b. Perputaran Persediaan Inventory Turn Over (ITO)

Rasio ini yang digunakan untuk mengukur berapa kali dana yang ditanam dalam persediaan ini berputar dalam suatu periode.

Rumus untuk menghitung Inventory Turn Over (ITO) dapat dirumuskan sebagai berikut :

\begin{tabular}{|c|}
\hline Inventory Turn Over $=\frac{\text { Penjualan }}{\text { Persediaan }}$ \\
\hline Gambar 2.9. Rumus Menghitung Inventory Turn Over (ITO) \\
\hline Sumber: Kasmir, (2016:181) \\
\hline
\end{tabular}

c. Perputaran Modal Kerja Working Turn Over (WTO)

Perputaran Modal Kerja Working Turn Over (WTO) merupakan rasio yang digunakan untuk mengukur atau menilai keefektifan modal kerja berputar selama satu periode atau dalam suatu periode.

Rumus untuk menghitung Working Turn Over (WTO) dapat dirumuskan sebagai berikut:

\begin{tabular}{|c|} 
Working Turn Over $=\frac{\text { Penjualan bersih }}{\text { Modal } \text { kerja }}$ \\
\hline Gambar 2.10. Rumus Menghitung Working Turn Over (WTO) \\
\hline Sumber: Kasmir, (2016:183) \\
\hline
\end{tabular}

\section{d. Total Assets Turn Over (TATO)}

Total Assets Turn Over (TATO) merupakan rasio yang digunakan untuk mengukur perputaran semua aktiva yang dimiliki perusahaan dan mengukur berapa jumlah penjualan yang diperoleh dari setiap rupiah aktiva.

Rumus untuk menghitung Total Assets Turn Over (TATO) dapat dirumuskan sebagai berikut:

$$
\begin{aligned}
& \text { Total Assets Turn Over }=\frac{\text { Penjualan }}{\text { Total Aktiva }} \\
& \text { Gambar 2.11. Rumus Menghitung Total Assets Turn Over (TATO) } \\
& \text { Sumber: Kasmir, (2016:183) }
\end{aligned}
$$

\section{Profitabilitas (Earning) \\ Definisi Profitabilitas}

Menurut Hery (2014:192) profitabilitas merupakan rasio yang menggambarkan kemampuan perusahaan dalam menghasilkan laba melalui semua kemampuan dan sumber daya yang dimilikinya, yaitu yang berasal dari kegiatan penjualan, penggunaan aset, maupun penggunaan modal dapat digunakan sebagai alat untuk mengukur efektivitas kinerja manajemen. Kinerja yang baik terlihat dari keberhasilan manajemen dalam menghasilkan laba yang maksimal bagi perusahaan.

\section{Jenis-Jenis Profitabilitas}

Berikut adalah jenis-jenis profitabilitas yang lazim digunakan untuk mengukur kemampuan perusahaan dalam menghasilkan laba.

a. Gross Profit Margin (GPM)

Gross Profit Margin (GPM) adalah rasio yang digunakan untuk mengetahui presentasi laba dari kegiatan usaha murni dari bank yang bersangkutan setelah dikurangi biayabiaya.

Rumus untuk menghitung Gross Profit Margin (GPM) dapat dirumuskan sebagai berikut :

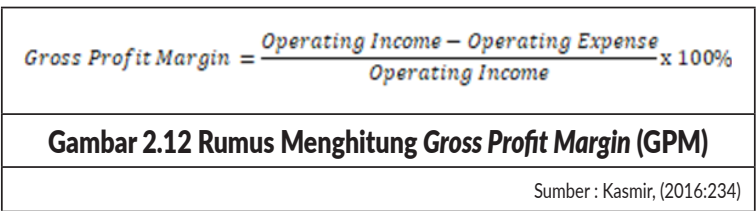

\begin{tabular}{|c|c|}
\hline \multicolumn{2}{|c|}{ Tabel 2.6. Matriks Kategori Gross Profit Margin (GPM) } \\
\hline Kategori & Hasil Rasio \\
\hline Sehat & GPM $>28,42 \%$ \\
\hline Tidak Sehat & GPM $<28,42 \%$ \\
\hline \multicolumn{2}{|c|}{ Sumber: SPI- Vol. 16 No. 10, September 2018} \\
\hline
\end{tabular}

b. Net Profit Margin (NPM)

Net Profit Margin (NPM) merupakan rasio yang digunakan untuk mengukur kemampuan bank dalam menghasilkan pen- 
dapatan dengan perbandingan antara laba bersih dengan penjualan.

Rumus untuk menghitung Net Profit Margin (NPM) adalah sebagai berikut :

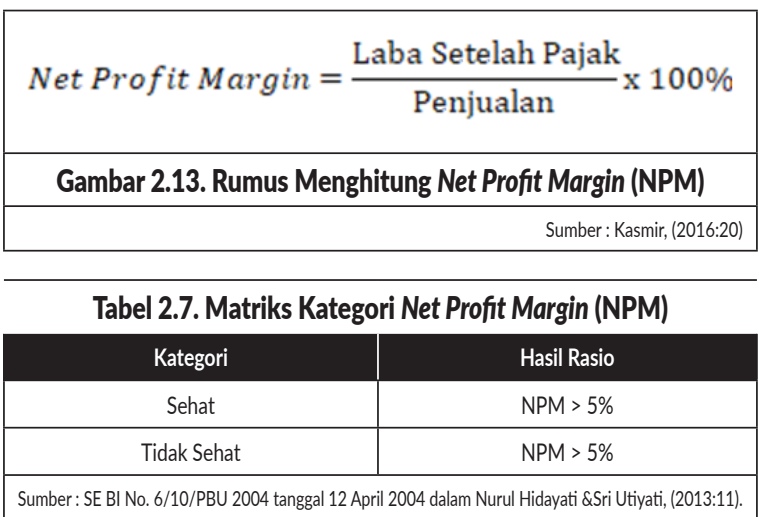

b. Return On Assets (ROA)

Return on Assets (ROA) merupakan rasio yang digunakan untuk mengukur kemampuan manajemen bank dalam memperoleh keuntungan (laba) secara keseluruhan.

Rumus untuk menghitung Return on Assets (ROA) dapat dirumuskan sebagai berikut :

\begin{tabular}{|c|}
\hline Return on Asset $=\frac{\text { Laba Sebelum Pajak }}{\text { Total Asset }} \times 100 \%$ \\
\hline Gambar 2.14. Rumus Menghitung Return on Assets (ROA) \\
\hline Sumber : Lampiran SE BI No.6/23/DPNP tahun 2004 \\
\hline
\end{tabular}

Tabel 2.8. Matriks Kategori Return on Assets (ROA)

\begin{tabular}{|c|c|}
\hline Kategori & Hasil Rasio \\
\hline Sehat & ROA $>2,50 \%$ \\
\hline Tidak Sehat & ROA $<2,50 \%$ \\
\hline & Sumber : SPI-Vol. 16 No. 10, September 2018 \\
\hline
\end{tabular}

c. Return on Equity (ROE)

Return on Equity (ROE) adalah perbandingan antara laba bersih dengan modal sendiri. Rasio ini merupakan indikator bagi para pemegang saham dan calon investor untuk mengukur kemampuan bank dalam memperoleh keuntungan bersih dikaitkan dengan pembayaran deviden.

Rumus untuk menghitung Return on Equity (ROE) adalah sebagai berikut :

\begin{tabular}{|c|}
\hline Return on Equity $=\frac{\text { Laba Setelah Pajak }}{\text { Total Modal }} \times 100 \%$ \\
\hline Gambar 2.1. Rumus Menghitung Return on Equity (ROE) \\
Sumber : Lampiran SE BI No.6/23/DPNP tahun 2004 \\
\hline
\end{tabular}

Tabel 2.9. Matriks Kategori Return on Equity (ROE)

\begin{tabular}{|c|c|}
\hline Kategori & Hasil Rasio \\
\hline Sehat & ROE $>14,61 \%$ \\
\hline Tidak Sehat & ROE $<14,61 \%$ \\
\hline & Sumber: SPI- Vol. 16 No. 10, September 2018 \\
\hline
\end{tabular}

d. Beban Operasional Pendapatan Operasional (BOPO)

Beban Operasional Pendapatan Operasional (BOPO) adalah perbandingan antara biaya operasional dan pendapatan operasional. Rasio ini digunakan untuk mengukur tingkat efisiensi dan kemampuan bank dalam melakukan kegiatan operasinya.

Rumus untuk menghitung Beban Operasional Pendapatan Operasional (BOPO) dapat dirumuskan sebagai berikut :

\begin{tabular}{|c|c|}
\hline \multicolumn{2}{|c|}{ Beban Operasional Pendapatan Operasional $=\frac{\text { Beban Operasional }}{\text { Pendapatan Operasional }} \times 100 \%$} \\
\hline \multicolumn{2}{|c|}{$\begin{array}{l}\text { Gambar 2.16. Rumus Menghitung Beban } \\
\text { Operasional Pendapatan Operasional (BOPO) }\end{array}$} \\
\hline \multicolumn{2}{|r|}{ Sumber : Lampiran SE BI No.6/23/DPNP Tahun 2004} \\
\hline \multicolumn{2}{|c|}{$\begin{array}{l}\text { Tabel 2.10. Matriks Kategori Beban } \\
\text { Operasional Pendapatan Operasional (BOPO) }\end{array}$} \\
\hline Kategori & Hasil Rasio \\
\hline Sehat & BOPO $<79,13 \%$ \\
\hline Tidak Sehat & $\mathrm{BOPO}>79,13 \%$ \\
\hline
\end{tabular}

e. Laba Per Lembar Saham Biasa Earning Per Share of Common Stock (EPS)

Laba Per Lembar Saham Biasa Earning Per Share of Common Stock (EPS) disebut juga rasio nilai buku merupakan rasio untuk mengukur keberhasilan manajemen dalam mencapai keuntungan bagi pemegang saham dengan cara perbandingan laba saham biasa dengan saham biasa yang beredar.

Rumus menghitung Earning Per Share of Common Stock (EPS) dapat dirumuskan sebagai berikut : 


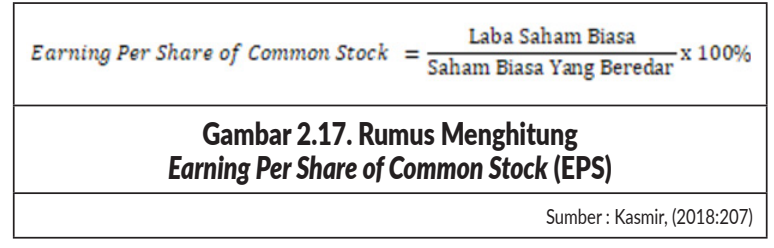

\section{METODE}

\section{Ruang Lingkup Penelitian}

1. Lokasi Penelitian

Penelitian ini dilaksanakan dengan menggunakan data sekunder Laporan Keuangan dari PT Bank Mandiri (Persero) Tbk. Yang diperoleh dari website resmi periode : https:// www.bankmandiri.co.id/web/ir/annualreports periode tahun 2012 sampai dengan tahun 2017.

2. Sifat Penelitian

Penelitian yang digunakan oleh penulis bersifat deskriptif kuantitatif, yaitu data-data yang bersifat angka menurut Sugiyono (2009:23) dalam Mitra Adri Anus (2017:66). Penelitian yang dilakukan dengan menganalisis data dengan cara men deskripsikan atau bermaksud membuat kesimpulan yang bersifat umum atau generalisasi menurut Sugiyono (2006:143) dalam Mitra adri anus (2017:66). Dalam hal ini penulis mendeskripsikan, mencatat, menganalisis, dan menginterprestasikan laporan keuangan perusahaan.

\section{Waktu Penelitian}

Proses penelitian yang akan penulis laksanakan diharapkan dapat selesai dalam 8 bulan, mulai dari seminar usulan penelitian sampai menyelesaikan skripsi.

\section{Populasi dan Sampel Penelitian}

1. Populasi

Menurut Sugiyono (2016:215) populasi adalah wilayah generalisasi yang atas : objek/ subjek yang mempunyai kualitas dan karakteristik tertentu yang ditetapkan oleh peneliti untuk dipelajari dan kemudian ditarik kesimpulannya. Populasi yang digunakan dalam penelitian ini adalah laporan keuangan PT Bank Mandiri (Persero) Tbk.

\section{Sampel}

Menurut Sugiyono (2016:215) sampel adalah bagian dari populasi itu. Dikarenakan keterbatasan dana, tenaga, dan waktu, maka peneliti mengambil sampel berupa neraca, dan laporan laba rugi PT Bank Mandiri (Persero) Tbk dan anak perusahaan pada tahun 2012 sampai tahun 2017 yang diperoleh dari website resmi PT Bank Mandiri (Persero) Tbk yaitu http://www.Mandiri.co.id dan Otoritas Jasa Keuangan yaitu https://ojk. go.id.

\section{Metode Pengumpulan Data}

Sesuai dengan jenis data dalam penelitian ini adalah data sekunder, maka teknik pengumpulan data yang digunakan adalah sebagai berikut :

\section{Kepustakaan (Library Research)}

Kepustakaan adalah teknik pengumpulan data yang diperoleh dengan membaca dan memahami dari buku-buku seperti, buku manajemen keuangan, analisis laporan keuangan, bank dan lembaga keuangan lainnya, dan hal lain yang berhubungan dengan aspek yang diteliti sebagai upaya untuk memperoleh data yang valid.

\section{Dokumentasi}

Dokumen adalah teknik pengumpulan data yang diperoleh dengan mencatat atau manggandakan dokumen-dokumen. Datadata atau dokumen yang digunakan peneliti dalam penelitian ini berupa laporan keuangan (neraca dan laporan laba rugi) maupun laporan tahunan (Annual Report) yang telah dipublikasikan secara resmi baik dari Bursa Efek Indonesia (BEI), maupun PT Bank Mandiri (Persero) Tbk, serta penelitian terdahulu yang nantinya akan dianalisis dan diambil kesimpulannya.

\section{Internet Research}

Terkadang buku referensi atau literatur yang kita miliki atau pinjam diperpustakaan telah ada selama beberapa waktu atau kadaluwarsa, karena ilmu selalu berkembang penulis melakukan penelitian dengan teknologi berkembang yaitu dengan internet sehingga data yang diperoleh up to date. 


\section{Metode Analisis Data}

Penelitian ini menggunakan metode analisis deskriptif dan kuantitatif, yaitu menjelaskan penilaian tingkat kesehatan bank dengan menggunakan rasio likuiditas dan profitabilitas yang kemudian membandingkannya dengan statistik perbankan Indonesia -Vol. 16 No. 10, September 2018. Sehingga, diperolehlah hasil penilaian tingkat kesehatan bank sesuai dengan statistik perbankan Indonesia -Vol. 16 No. 10, September 2018.

Menurut Sofyan Safri Harahap (2008:304) dalam Mitra Adri Anus (2017: 74), rasio profitabilitas adalah kemampuan perusahaan dalam mendapatkan laba melalui semua kemampuan, sumber yang ada seperti kegiatan penjualan, kas, modal, jumlah cabang dan sebagainya.

Dalam mengukur rasio likuiditas dan profitabilitas, metode analisa dapat dilakukan dengan menggunakan rasio sebagai berikut :

1. Return on Assets (ROA)

Menurut Kasmir (2012:2015) Return on Assets (ROA) atau rentabilitas ekonomi merupakan rasio yang digunakan untuk mengukur laba bersih sebelum pajak dengan total seluruh aktiva. Rasio ini menunjukkan efesiensi penggunaan aktiva secara keseluruhan.

Rumus untuk menghitung Return on Assets (ROA) adalah sebagai berikut :

$$
\begin{gathered}
\text { Return on Asset }=\frac{\text { Laba Sebelum Pajak }}{\text { Total Asset }} \times 100 \% \\
\text { Gambar 3.1. Rumus Menghitung Return on Assets (ROA) } \\
\text { Sumber : Lampiran SE BI No.6/23/DPNP tahun } 2004
\end{gathered}
$$

2. Return on Equity (ROE)

Menurut Kasmir (2012:204) Return on Equity atau rentabilitas modal sendiri merupakan rasio yang digunakan untuk mengukur laba bersih sesudah pajak dengan modal sendiri. Rasio ini menunjukkan efesiensi penggunaan modal sendiri.

Rumus untuk menghitung Return on Equity (ROE) dapat dirumuskan sebagai berikut :

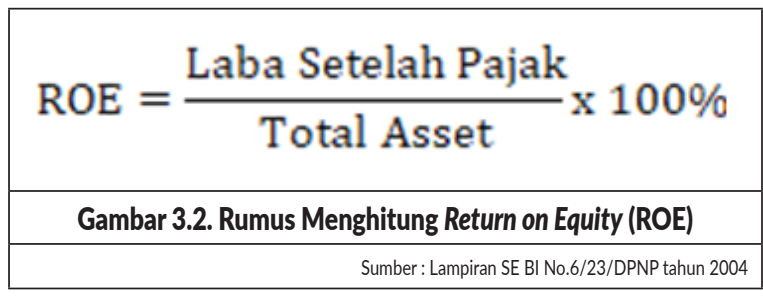

Adapun langkah-langkah dalam melakukan analisis data dapat diperinci sebagai berikut:

1. Mereview dan mengumpulkan data yang berhubungan dengan rasio Return on Assets (ROA dan rasio Return on Equity (ROE).

2. Menghitung nilai indikator dari masingmasing Return on Assets (ROA), Return on Equity (ROE) sehingga diperoleh nilai dari masing-masing rasio.

3. Lalu membandingkan nilai rata-rata Rasio Profitabilitas yaitu Return on Assets (ROA), Return on Equity (ROE) yang telah diperoleh dengan matriks kategori dari masing-masing rasio yang mengacu pada Surat Edaran Bank Indonesia No 6/23/DPNP/Tahun 2004 dan Statistik Perbankan Indonesia -Vol. 16 No. 10, September 2018.

4. Sehingga dapat diperoleh kesimpulan mengenai tingkat kesehatan kinerja keuangan pada PT Bank Mandiri (Persero) Tbk apakah berada dalam kondisi sehat, atau tidak sehat.

\section{HASIL dan PEMBAHASAN}

\section{Data Laporan Keuangan PT Bank Mandiri} (Persero) Tbk

Berikut ini ringkasan Laporan Keuangan PT Bank Mandiri (Persero) Tbk 31 Desember 2012 sampai dengan 31 Desember 2017.

a. Total Asset PT Bank Mandiri (Persero) Tbk selama tahun 2012-2017 cenderung mengalami peningkatan secara berturut-turut yaitu tahun 2012 sebesar Rp635.619 miliar, tahun 2013 sebesar Rp733.100 miliar, tahun 2014 sebesar Rp855.040 miliar, tahun 2015 sebesar Rp910.063 miliar, tahun 2016 sebesar Rp1.038.706 miliar, dan tahun 2017 sebesar Rp1.124.701 miliar. Di mana nilai tertinggi terjadi pada tahun 2017 atau tumbuh sekitar $8,28 \%$ dan nilai terendah terjadi pada tahun 2012 atau tumbuh sekitar $0 \%$, sehingga nilai 
rata-rata total asset sebesar Rp882.871,500 miliar atau tumbuh sekitar $12,17 \%$.

b. Laba sebelum pajak PT Bank Mandiri (Persero) Tbk selama tahun 2012-2017 cenderung mengalami peningkatan secara berturutturut yaitu tahun 2012 sebesar Rp20.504 miliar, tahun 2013 sebesar Rp24.062 miliar, tahun 2014 sebesar Rp26.008 miliar, tahun 2015 sebesar Rp26.369 miliar, dan tahun 2017 sebesar Rp27.157 miliar. Kecuali, pada tahun 2016 laba sebelum pajak PT Bank Mandiri (Persero) Tbk mengalami penurunan sekitar 29,57\% menjadi sekitar sebesar Rp18.573 miliar. Dimana nilai tertinggi terjadi pada tahun 2017 atau tumbuh sekitar 8,28\% dan nilai terendah terjadi pada tahun 2012 atau tumbuh sekitar $0 \%$, sehingga rata-rata laba sebelum pajak menjadi sebesar Rp23.945,50 miliar atau tumbuh sekitar 8,72\%.

c. Laba setelah pajak PT Bank Mandiri (Persero) Tbk selama tahun 2012-2017 cenderung mengalami peningkatan secara berturutturut yaitu tahun 2012 sebesar Rp16.044 miliar, tahun 2013 sebesar Rp18.830 miliar, tahun 2014 sebesar Rp20.655 miliar, tahun 2015 sebesar Rp21.152 miliar, tahun 2107 sebesar Rp21.443 miliar. Kecuali, di tahun 2016 laba setelah pajak PT Bank Mandiri (Persero) Tbk mengalami penurunan sekitar 30,74\% menjadi sekitar sebesar Rp14.650 miliar. Dimana nilai tertinggi terjadi pada tahun 2017 atau tumbuh sekitar 46,37\% dan nilai terendah terjadi pada tahun 2012 atau tumbuh sekitar $0 \%$, sehingga rata-rata laba sebelum pajak menjadi sebesar Rp18.795,67 miliar atau tumbuh sekitar 9,02\% ratarata laba sebelum pajak menjadi sebesar Rp18.795,67 miliar atau tumbuh sekitar 9,02\%.

d. Total Modal PT Bank Mandiri (Persero) Tbk selama tahun 2012-2017 cenderung mengalami peningkatan secara berturutturut yaitu tahun 2012 sebesar Rp75.756 miliar, tahun 2013 sebesar Rp88.791 miliar, tahun 2014 sebesar Rp104.845 miliar, tahun 2015 sebesar Rp119.492 miliar, tahun 2016 sebesar Rp170.006 miliar. Kecuali di tahun
2017 total Modal PT Bank Mandiri (Persero) Tbk mengalami penurunan sekitar 9,79\% menjadi sekitar sebesar Rp153.370 miliar. Di mana nilai tertinggi terjadi pada tahun 2016 atau tumbuh sekitar $42,21 \%$ dan nilai terendah terjadi pada tahun 2012 atau tumbuh sekitar $0 \%$, sehingga nilai rata-rata total Modal sebesar Rp118.710 miliar atau tumbuh sekitar 16,35\%.

2. Perhitungan Rasio Keuangan Untuk Menilai Kinerja Keuangan Pada PT Bank Mandiri (Persero) Tbk

a) Return on Assets (ROA)

Return on Assets (ROA) digunakan untuk mengukur kemampuan manajemen bank dalam memperoleh keuntungan secara keseluruhan. Semakin besar Return on Assets (ROA) PT Bank Mandiri (Persero) Tbk, maka semakin baik tingkat keuntungan bank dan semakin baik posisi bank dari segi penggunaan asetnya. Artinya tingkat keuntungan PT Bank Mandiri (Persero) Tbk akan semakin besar.

Perhitungan Return on Assets (ROA) PT Bank Mandiri (Persero) Tbk selama enam tahun terakhir sebagai berikut :

\begin{tabular}{|c|c|c|c|c|c|c|}
\hline \multicolumn{7}{|c|}{$\begin{array}{l}\text { Tabel 4.4. Perhitungan Return on Assets (ROA) } \\
\text { PT Bank Mandiri (Persero) Tbk } \\
1 \text { Desember 2012-2017 (Dalam Jutaan Rupiah \&\%) }\end{array}$} \\
\hline Uraian & 2012 & 2013 & 2014 & 2015 & 2016 & 2016 \\
\hline $\begin{array}{l}\text { Laba } \\
\text { Sebelum } \\
\text { Pajak }\end{array}$ & 20.504 .268 & 24.061.837 & 26.008 .015 & 26.369 .430 & 18.573 .965 & 27.156 .863 \\
\hline $\begin{array}{l}\text { Total } \\
\text { Aset }\end{array}$ & 635.618 .708 & 733.099 .762 & 855.039 .673 & 910.063 .409 & 1.038 .706 .009 & 1.124 .700 .847 \\
\hline ROA & $3,22 \%$ & $3,28 \%$ & $3,04 \%$ & $2,90 \%$ & $1,79 \%$ & $2,42 \%$ \\
\hline
\end{tabular}

Return on Assets (ROA) tahun 2012 : Laba Sebelum Pajak sebesar Rp20.504.268,-. Total Aset sebesar Rp635.618.708,-. Maka, Return on Assets (ROA) pada tahun 2012 :

$$
\begin{aligned}
\text { Return on Assets (ROA) }= & \frac{\text { Laba Sebelum Pajak }}{\text { Total Asset }} \times 100 \% \\
& =\frac{\operatorname{Rp~} 20.504 .268,-}{\operatorname{Rp~} 635.618 .708,-} \times 100 \% \\
& =3,22 \%
\end{aligned}
$$

Return on Assets (ROA) tahun 2013 : Laba Sebelum Pajak sebesar Rp24.061.837,- 
. Total Aset sebesar Rp733.099.762,- Maka, Return on Assets (ROA) pada tahun 2014 :

$$
\begin{aligned}
\text { Return on Assets (ROA) }= & \frac{\text { Laba Sebelum Pajak }}{\text { Total Asset }} \times 100 \% \\
& =\frac{\operatorname{Rp~24.061.837,-}}{\operatorname{Rp~733.099.76,-}} \times 100 \% \\
& =3,28 \%
\end{aligned}
$$

Return on Assets (ROA) tahun 2014 : Laba Sebelum Pajak pada tahun 2014 adalah sebesar Rp26.008.015,-. Total Aset pada tahun 2014 sebesar Rp855.039.673,-. Maka, Return on Assets (ROA) pada tahun 2014 :

$$
\begin{aligned}
\text { Return on Assets }(\mathrm{ROA})= & \frac{\text { Laba Sebelum Pajak }}{\text { Total Asset }} \times 100 \% \\
& =\frac{\operatorname{Rp~} 26.008 .015,-}{\operatorname{Rp~} 855.039 .678,-} \times 100 \% \\
& =3,04 \%
\end{aligned}
$$

Return on Assets (ROA) tahun 2015 : Laba Sebelum Pajak sebesar Rp26.369.430,-. Total Aset sebesar Rp910.063.409,-. Maka, Return on Assets (ROA) pada tahun 2015 :

$$
\begin{aligned}
\text { Return on Assets (ROA) } & =\frac{\text { Laba Sebelum Pajak }}{\text { Total Asset }} \times 100 \% \\
& =\frac{\operatorname{Rp~} 26.369 .430,-}{\operatorname{Rp~} 910.063 .409,-} \times 100 \% \\
& =2,90 \%
\end{aligned}
$$

Return on Assets (ROA) tahun 2016 : Laba Sebelum Pajak sebesar Rp18.572.965,- Total Aset sebesar Rp1.038.706.009,-. Maka, Return on Assets (ROA) pada tahun 2016 :

$$
\begin{aligned}
\text { Return on Assets (ROA) } & =\frac{\text { Laba Sebelum Pajak }}{\text { Total Asset }} \times 100 \% \\
& =\frac{\operatorname{Rp~} 18.572 .965,-}{\operatorname{Rp~} 1.038 .706 .009,-} \times 100 \% \\
& =1,79 \%
\end{aligned}
$$

Return on Assets (ROA) tahun 2017 : Laba Sebelum Pajak sebesar Rp27.156.863,- Total Aset sebesar Rp1.124.701.847,-. Maka, Return on Assets (ROA) pada tahun 2017 :

$$
\begin{aligned}
\text { Return on Assets (ROA) } & =\frac{\text { Laba Sebelum Pajak }}{\text { Total Asset }} \times 100 \% \\
& =\frac{\operatorname{Rp~} 27.156 .863,-}{\operatorname{Rp~1.124.701.847,-}} \times 100 \% \\
& =2,42 \%
\end{aligned}
$$

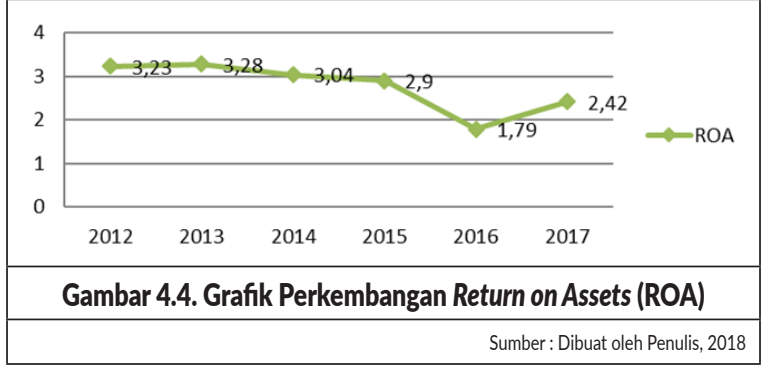

Perhitungan dan grafik perkembangan Return on Assets (ROA) di atas terlihat bahwa selama enam (6) tahun terakhir terjadi kecenderungan berfruktuasi. Perkembangan Return on Assets (ROA) PT Bank Mandiri (Persero) Tbk yaitu pada tahun 2012 memperoleh sekitar 3,23\%, dan mengalami peningkatan pada tahun 2013 sekitar 0,05\% yaitu menjadi sekitar 3,28\%.

Namun, pada tahun 2014, sampai tahun 2016 Return on Assets (ROA) PT Bank Mandiri (Persero) Tbk mengalami penurunan yaitu sekitar $41,12 \%$ menjadi sekitar 3,04\%, 2,90\%, dan 1,79\%. Dan kembali mengalami peningkatan yang cukup signifikan pada

\begin{tabular}{|c|c|c|c|c|c|c|}
\hline \multicolumn{7}{|c|}{$\begin{array}{l}\text { Tabel 4.5. Perhitungan Return on Equity (ROE) } \\
\text { PT Bank Mandiri (Persero) Tbk } \\
\text { 31 Desember 2012-2017 (Dalam Jutaan Rupiah) }\end{array}$} \\
\hline Uraian & 2012 & 2013 & 2014 & 2015 & 2016 & 2016 \\
\hline $\begin{array}{l}\text { Laba } \\
\text { Sebelum } \\
\text { Pajak }\end{array}$ & 16.043 .618 & 18.829 .934 & 20.654 .783 & 21.152 .398 & 14.650.163 & 21.443 .042 \\
\hline $\begin{array}{l}\text { Total } \\
\text { Modal }\end{array}$ & 75.755 .589 & $88.790 .5 \%$ & 104.84.562 & 119.491 .841 & 153.369 .723 & 170.006 .132 \\
\hline ROE & $21,18 \%$ & $21,21 \%$ & $19,70 \%$ & $17,70 \%$ & $9,55 \%$ & $12,61 \%$ \\
\hline
\end{tabular}
tahun 2017 yaitu sekitar 0,63\%.

Dengan demikian dapat diketahui bahwa selama enam (6) tahun terakhir rata-rata Return on Assets (ROA) PT Bank Mandiri (Persero) Tbk sebesar 2,78\%.

b) Return on Equity (ROE)

Return on Equity (ROE) digunakan untuk menunjukkan efisiensi penggunaan modal sendiri. Semakin besar Return on Equity (ROE) PT Bank Mandiri (Persero) Tbk, maka semakin baik posisi PT Bank Mandiri (Persero) Tbk dari segi penggunaan modal. Artinya posisi pemilik perusahaan akan semakin kuat. 
Return on Equity (ROE) tahun 2012 : Laba setelah pajak sebesar Rp16.043.618,-. Total modal sebesar Rp75.755.589,-. Maka, Return on Equity (ROE) pada tahun 2012 adalah:

$$
\begin{aligned}
\text { Return on Equity (ROE) }) & =\frac{\text { Laba Setelah Pajak }}{\text { Total Modal }} \times 100 \% \\
& =\frac{\operatorname{Rp~16.043.618,-}}{\operatorname{Rp~75.755.589,-}} \times 100 \% \\
& =21,18 \%
\end{aligned}
$$

Return on Equity (ROE) tahun 2013 : Laba setelah pajak sebesar Rp18.829.934,Total modal sebesar Rp88.790.596,-. Maka, Return on Equity (ROE) pada tahun 2013 adalah :

Return on Equity $(\mathrm{ROE})=\frac{\text { Laba Setelah Pajak }}{\text { Total Modal }} \times 100 \%$

$$
\begin{aligned}
& =\frac{\operatorname{Rp~18.829.934,-}}{\operatorname{Rp~88.790.596,-}} \times 100 \% \\
& =21,20 \%
\end{aligned}
$$

Return on Equity (ROE) tahun 2014 : Laba setelah pajak sebesar Rp20.654.783,. Total sebesar Rp104.844.562,-. sebesar Rp104.844.562,-. Maka, Return on Equity (ROE) pada tahun 2014 adalah :

$$
\begin{aligned}
\text { Return on Equity (ROE) } & =\frac{\text { Laba Setelah Pajak }}{\text { Total Modal }} \times 100 \% \\
& =\frac{\operatorname{Rp~} 20.654 .783,-}{\operatorname{Rp~} 104.844 .562,-} \times 100 \% \\
& =19,70 \%
\end{aligned}
$$

Return on Equity (ROE) tahun 2015: Laba setelah pajak sebesar Rp21.152.398,-. Total modal sebesar Rp119.491.841,-. Maka, Return on Equity (ROE) pada tahun 2015 adalah :

$$
\begin{aligned}
\text { Return on Equity }(\mathrm{ROE}) & =\frac{\text { Laba Setelah Pajak }}{\text { Total Modal }} \times 100 \% \\
& =\frac{\operatorname{Rp~} 21.152 .398,-}{\operatorname{Rp} 119.491 .841,-} \times 100 \% \\
& =17,70 \%
\end{aligned}
$$

Return on Equity (ROE) tahun 2016: Laba setelah pajak sebesar Rp14.650.163,-Total modal sebesar Rp153.369.723,-. Maka, Return on Equity (ROE) pada tahun 2016 adalah :

$$
\begin{aligned}
& \text { Return on Equity (ROE) } \begin{aligned}
& =\frac{\text { Laba Setelah Pajak }}{\text { Total Modal }} \times 100 \% \\
& =\frac{\operatorname{Rp~} 14.650 .163,-}{\operatorname{Rp~} 153.369 .723,-} \times 100 \% \\
& =9,55 \%
\end{aligned}
\end{aligned}
$$

Return on Equity (ROE) tahun 2017: Laba setelah pajak sebesar Rp21.443.042,-Total modal sebesar Rp170.006.132,-. Maka, Return on Equity (ROE) pada tahun 2017 adalah :

$$
\begin{aligned}
\text { Return on Equity (ROE) } & =\frac{\text { Laba Setelah Pajak }}{\text { Total Modal }} \times 100 \% \\
& =\frac{\operatorname{Rp~} 21.443 .043 .-}{\operatorname{Rp} 170.006 .132 .-} \times 100 \% \\
& =12,61 \%
\end{aligned}
$$

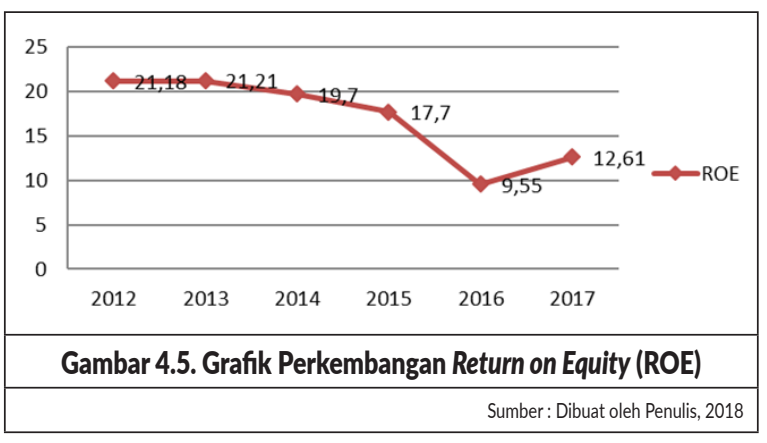

Dari perhitungan dan grafik perkembangan Return on Equity (ROE) di atas terlihat bahwa selama enam (6) tahun terakhir terjadi kecenderungan fruktuatif mengalami naik turun. Perkembangan Return on Equity (ROE) PT Bank Mandiri (Persero) Tbk yaitu pada tahun 2012 memperoleh sekitar $21,18 \%$, dan mengalami peningkatan pada tahun 2013 sekitar 0,03\% yaitu menjadi sekitar 21,21\%.

Namun, pada tahun 2014 sampai tahun 2016 Return on Equity (ROE) PT Bank Mandiri (Persero) Tbk mengalami penurunan yaitu sekitar 51,52\% menjadi sekitar 19,7\%, 17,7\%, dan 9,55\%. Kemudian, mengalami peningkatan kembali yang cukup signifikan pada tahun 2017 yaitu, sekitar $3,06 \%$ menjadi sekitar $12,61 \%$.

Dengan demikian dapat diketahui bahwa selama enam (6) tahun terakhir rata-rata 
Return on Equity (ROE) PT Bank Mandiri (Persero) Tbk sekitar 16,99\%.

\section{Kinerja Keuangan PT Bank Mandiri (Persero) Tbk}

Untuk mengukur kinerja keuangan atau tingkat kesehatan keuangan pada PT Bank Mandiri (Persero) Tbk, penulis melakukan perhitungan rata-rata terlebih dahulu untuk rasio keuangan yang diteliti. Setelah itu, hasilnya diperbandingkan dengan Statistik Perbankan Indonesia -Vol. 16 No. 10, September 2018.

Adapun perhitungan rata-rata rasio Return on Assets (ROA), Return on Equity (ROE) Statistik Perbankan Indonesia dan kinerja keuangan PT Bank Mandiri (Persero) Tbk adalah sebagai berikut :

\begin{tabular}{|c|r|c|r|c|}
\hline \multicolumn{5}{|c|}{ Tabel 4.6. Kinerja Keuangan } \\
\hline PT Bank Mandiri (Persero) Tbk Tahun 2012-2017 \\
\hline Tahun & ROA & SPI =>2,50 & \multicolumn{1}{c|}{ ROE } & SPI =>14,61 \\
\hline 2012 & $3,23 \%$ & Sehat & $21,18 \%$ & Sehat \\
\hline 2013 & $3,28 \%$ & Sehat & $21,21 \%$ & Sehat \\
\hline 2014 & $3,04 \%$ & Sehat & $19,70 \%$ & Sehat \\
\hline 2015 & $2,90 \%$ & Sehat & $17,70 \%$ & Sehat \\
\hline 2016 & $1,79 \%$ & Tidak Sehat & $9,55 \%$ & Tidak Sehat \\
\hline 2017 & $2,42 \%$ & Tidak Sehat & $12,61 \%$ & Tidak Sehat \\
\hline Rata-rata & $2,78 \%$ & Sehat & $16,99 \%$ & Sehat \\
\hline & & \multicolumn{3}{c}{ Sumber : Diolah oleh penulis, 2018 } \\
\hline
\end{tabular}

Berdasarkan data hasil analisis rasio di atas dapat diukur kinerja keuangan untuk setiap rasio yang telah dibandingkan dengan statistik perbankan indonesia, maka dapat dianalisis sebagai berikut:

1. Return on Assets (ROA)

Return on Assets (ROA) PT Bank Mandiri (Persero) Tbk pada tahun 2012 sampai dengan tahun 2015 dengan memperoleh predikat sehat, sedangkan pada tahun 2016 dan tahun 2017 memperoleh predikat tidak sehat. Hal ini dikarenakan nilai Return on Assets (ROA) lebih kecil dari standar yang ada yakni $(<2,50 \%)$ Statistik Perbankan Indonesia- Vol. 16 No. 10, Bulan September 2018. Namun secara keseluruhan kinerja keuangan mengenai ROA pada PT Bank Mandiri (perero) Tbk memperoleh predikat sehat, denga nilai sebesar $2,78 \%$.
2. Return on Equity (ROE)

Return on Equity (ROE) PT Bank Mandiri (Persero) Tbk pada tahun 2012 sampai dengan tahun 2017 memperoleh predikat sehat, sedangkan pada tahun 2016 dan tahun 2017 memperoleh predikat tidak sehat. Hal ini dikarenakan nilai Return on Equity (ROE) lebih besar dari $(<14,61)$ Statistik Perbankan Indonesia- Vol. 16 No. 10, Bulan September 2018. Namun secara keseluruhan kinerja keuangan mengenai ROE pada PT Bank Mandiri (perero) Tbk memperoleh predikat sehat, denga nilai sebesar $16,99 \%$.

\section{SIMPULAN}

\section{Kesimpulan}

Berdasarkan hasil dan pembahasan yang telah penulis lakukan maka, penulis dapat menarik kesimpulan sebagai berikut :

1. Pada perhitungan Return on Assets (ROA) pada PT Bank Mandiri (Persero) Tbk, menunjukkan bahwa kondisi perusahaan "sehat" dengan memperoleh nilai rata-rata Return on Assets (ROA) sekitar 2,78\% atau lebih besar dari (> 2,50\%) Statistik Perbankan Indonesia.

2. Pada perhitungan Return on Equity (ROE) pada PT Bank Mandiri (Persero) Tbk, menunjukkan bahwa kondisi perusahaan "sehat" dengan memperoleh nilai rata-rata Return on Equity (ROE) sekitar 16,99\% atau lebih besar dari (> 14,61\%) Statistik Perbankan Indonesia.

3. Kinerja keuangan pada PT. Bank Mandiri (Persero) Tbk yang dilihat dari hasil rasio Return on Assets (ROA) dan Return on Equity (ROE) menunjukkan bahwa kondisi perusahaan "sehat". Hal ini dikarenakan pihak manajemen telah dapat memanfaatkan aktiva, modal, dan mampu menekan biayabiayanya secara efektif dan efisien sehingga menghasilkan keuntungan yang cenderung mengalami peningkatan. Walaupun untuk kinerja keuangan pada PT Bank Mandiri (Persero) Tbk, baik untuk ROA maupun ROE di tahun 2016 dan 2017 memperoleh predikat kurang sehat. 


\section{Saran}

Adapun saran dalam penelitian ini merupakan salah satu bentuk kontribusi peneliti yang bisa dimanfaatkan oleh berbagai pihak khususnya bagi pihak PT Bank Mandiri (Persero) Tbk yaitu sebagai berikut :

1. Jika melihat pada tingkat profitabilitas Return on Assets (ROA), dan Return on Equity (ROE) PT Bank Mandiri (Persero) Tbk dari tahun 2012 sampai tahun 2017 yang cenderung mengalami peningkatan hendaknya dipertahankan untuk tahuntahun berikutnya dan untuk tahun yang mengalami penurunan hendaknya untuk melakukan perbaikan seperti melakukan atau menekan biaya operasional, agar di tahuntahun berikutnya PT Bank Mandiri (Persero) Tbk dapat memperoleh keuntungan yang lebih besar lagi.

2. Bagi perusahaan diharapkan dapat meningkatkan laba bank dengan cara meningkatkan jumlah aktiva produktif seperti kredit, penanaman dana dan penempatan dana dibanding dengan bentuk aktiva lainnya seperti rupa-rupa aktiva, aktiva tetap, dan inventaris serta meningkatkan produktivitas karyawan, melaunching produk baru yang lebih menarik, dan melakukan promosi besar-besaran, dan menurunkan biaya-biaya, serta menyisihkan dana untuk investasi.

3. Bagi para investor yang berminat dalam investasi saham di bank umum sebaiknya mempertimbangkan beberapa informasi aspek keuangan perbankan di antaranya ROA, dan ROE di bank umum tersebut.

\section{DAFTAR PUSTAKA}

Agung Yulianto \& Wiwit Apit Sulistyawati (2012) Analisis CAMELS Dalam Memprediksi Tingkat Kesehatan Bank Yang Terdaftar Di Bursa Efek Indonesia Periode Tahun 20092011. Fakultas Ekonomi Universitas Swadaya Gunung Jati Cirebon dan Universitas Pancasakti Tegal.

Auddy Teddy Pangalila, Parengkuan Tommy, Jantje Sepang (2015) Analisa Perbandingan
Kinerja Keuangan Bank Mandiri (Persero), Tbk, Bank Central Asia (Persero) Tbk, Bank Cimb Niaga (Persero) Tbk. Fakulatas Ekonomi dan Bisnis, Jurusan Manajemen Universitas Sam Ratulangi: Manado.

Dadang Prasetyo Jatmiko (2017) Pengantar Manajemen Keuangan, Diandra Kreatif : Yogyakarta.

Dwi Ayu Wulandari (2015) Analisis Perbandingan Kinerja Keuangan Dengan Pendekatan RGEC Di Negara ASEAN (Studi Pada Bank Umum Indonesia, Malaysia, Thailand, dan Singapura Tahun 2011-2014), Jurnal Ilmiah Jurusan Ilmu Ekonomi Fakultas Ekonomi \& Bisnis Universitas Brawijaya Malang.

Dwinta Juliana Rizkiyan (2014) Kinerja Keuangan Melalui Pendekatan Likuiditas, Solvabilitas, dan Rentabilitas Pada Perseroan Terbatas Perbankan. Program Studi Magister Manajemen Universitas Bina Darma.

Ferra Puji Yanti (2015) Rahasia Cepat Menguasai Laporan Keuangan Dalam Sekejab Otodidak Tanpa Guru Dengan Akuntansi Dasar. Lembar Pustaka Indonesia : Tangerang.

I Made Sudana (2015) Manajemen Keuangan Perusahaan Teori dan Praktik Edisi 2. Erlangga : Jakarta.

I Putu Snabowo dan Ni Gusti Putu Wirawati (2012) Analisis Tingkat Kesehatan Bank Menggunakan Rasio CAMEL Fakultas Ekonomi Universitas Udayana (Unud) Bali.

Ikatan Bankir Indonesia (IBI) (2016) Manajemen Kesehatan Bank Berbasis Risiko. Gramedia Pustaka Utama : Jakarta.

Jayanti Mandasari (2015) Analisis Kinerja Keuangan Dengan Pendekatan Metode RGEC Pada Bank BUMN Periode 20122013 Universtas Mulawarman. Jurnal lmu Administrasi Bisnis Volume 3 Nomor 2.

John Suprihanto (2014) Manajemen. Gajah Mada University Press : Yogyakarta.

Jopie Jusuf (2014) Analisis Kredit Untuk Credit (Account) Officer cet 13 : Jakarta.

Kasmir (2009) Pengantar Manajemen Keuangan. Surya Kencana Prenada Media Group : Jakarta.

Kasmir (2016) Analisis Laporan Keuangan Edisi 1 
Cet 9. Raja Grafindo Persada : Jakarta.

Kasmir (2017) Bank dan Lembaga Keuangan

Lainnya Edisi Revisi Cet 18. Rajawali Pers : Jakarta.

Leader Peace Mirdhani dan Budiyanto (2014) Analisis Rasio Camel Untuk Menilai Keseahtan Bank Pada Perusahaan LQ-45 Di $B E I$. Sekolah Tinggi Ilmu Ekonomi Indonesia (STIESIA) Surbaya, Jurnal Ilmu \& Riset Manajemen Vol.3 No 5 (2014).

Musthafa (2017) Manajemen Keuangan. Ansi Off Set : Yogyakarta.

Nardi Sunardi dan Linda Oktaviani (2016) Analisis CAMEL Dalam Menilai Tingkat Kesehatan Bank (Studi Kasus Pada Subsektor Perbankan Yang Terdaftar Di BEI Periode 2011-2015).

Nurfadilla Ayu Badarulla (2017) Analisis Kinerja Keuangan Dengan Menggunakan Rasio Likuiditas, Solvabilitas, dan Efisiensi Pada PT Bank Syariah Mandiri Fakultas Ekonomi dan Bisnis Islam Prodi D3 Perbankan Syariah Universitas Islam Skripsi NeGERI Raden Fatah Palembang.

Peter dan Jualianti, (2011) Penilaian Kinerja Keuangan PT Bank Central Asia, Tbk dengan Menggunakan Metode Economic Value Added Periode Tahun 2005-2009 sebagai Alat Pengukuran Kinerja Perusahaan. Jurnal Ilmiah Akuntansi. 5(2).

Primadia F. (2011). Kajian Kinerja Keuangan Pada PT Bank Internasional Indonesia, Tbk Periode 2004-2009. Skripsi. Fakultas Ekonomi dan Manajemen Institusi Pertanian Bogor.

Sabir, M, M. Ali dan Abd. Hamid H. (2012) Pengaruh Rasio Kesehatan Bank Terhadap Kinerja Keuangan Bank Umum Syariah dan Bank Konvensional di Indonesia. Jurnal Analisis 1 (1) h 79-86.

Sarinah dan Mardalena (2017) Pengantar Manajemen. Deepublish : Yogyakarta.

Sun C.C. (2011). Assessing Taiwan Financial Holdings Companies Performance Using Window Analysis And Malmquist Index. Arfrican Journal of Business Managemen . S (26), PP. 10508-10523.

Fauziyah Lissa (2018). "Analisis Profitabilitas Untuk MENILAI Kinerja Kuengan pt Mayora
Indah Tbk Periode 2011-2015”. Fakultas Ekonomi Universitas Pamulang : Tangerang Selatan.

Samlani (2016). "Analisis Rasio Profitabilitas dan Likuiditas Untuk Menilai Kinerja Keuangan Pada PT Hero Supermarket Tbk". Fakultas Ekonomi Universitas Pamulang: Tangerang Selatan.

Septiani Yola Dinda (2018). "Analisis Kinerja Keuangan Menggunakan Rasio Profitabilitas dan Likuiditas Pada PT Multistrada Arah Sarna”. Tbk Periode 2012-2017”. Program Studi Manajemen Universitas Pamulang : Tangerang Selatan.

Taqiyayah Rihanah (2018), " Analisis Likuiditas dan Rentabilitas Ekonomi Untuk Mengukur Kinerja Keuangan Pada PT Indoofoof CBP Sukses Makmur Tbk Tahun 2006-2015". Program Studi Manajemen Fakultas Ekonomi Universitas Pamulang : Tangerang Selatan.

Sari Lis Vina (2017) Analisis Tingkat Kesehatan Bank Dengan Menggunakan Metode RGEC Pada PT Bank Panin Tbk Program Studi Manajemen Fakultas Ekonomi Universitas Pamulang : Tangerang Selatan.

Internet :

https://databoks.katadata.co.id/ dat apublish/2018/03/15/10-bank denganasetterbesar-2017 diakses pada tanggal 6 April 2018 pukul 14:59.

https://www.bi.go.id/ diakses pada tanggal 08 april 2018 pukul 03:54.

https://www.Mandiri.co.id diakses pada tanggal 24 Desember 2018 16:37

https://ilmumanajemenindustri.com/pengertianrasio-kas-cash-ratio-rumus-rasiokas/diakses pada tanggal 24 Desember 2018 16:37. http://ozan993.blogspot.com/2014/12/retrunon-asset-roa.html diakses pada tanggal 25 Desember 2018 17:20. 